\title{
PENGARUH INFLASI, SUKU BUNGA DAN NILAI TUKAR TERHADAP RETURN SAHAM PADA PERUSAHAAN MANUFAKTUR DI BURSA EFEK INDONESIA PADA PERIODE 2013-2016
}

\author{
Hotmauli Sitanggang ${ }^{1}$, Kornel Munthe ${ }^{2}$ \\ Universitas Katolik Santo Thomas Medan Jl. Setia Budi No. 479F, 20132, Indonesia \\ e-mail: hotnaulistg@yahoo.com ${ }^{1}$, kornel_munthe@yahoo.com²
}

\begin{abstract}
This study aims to analyze and determine the effect of inflation, interest rates and exchange rates on stock returns on manufacturing companies that go public on the Indonesia Stock Exchange in the 20132014 period. The population in this study were 149 companies that went public on the Indonesia Stock Exchange in 2013-2016. By using the Slovin method, a sample of 60 companies was obtained. This type of data is secondary data obtained by documentation techniques. The data analysis technique used is multiple linear regression by testing hypotheses using $F$ and $t$. The results showed that partially inflation and interest rates had a negative and insignificant effect on stock returns while the rupiah exchange rate had a positive and significant effect on stock returns. Simultaneously that the variables of inflation, interest rates and exchange rates have a significant effect on stock returns on manufacturing companies that go public on the Indonesia Stock Exchange. The amount of variation in inflation, interest rates and exchange rates is only able to explain variations in stock returns by 4.4 percent, while the remaining 95.6 percent is explained by other variables outside of this research variable.
\end{abstract}

Keywords: Inflation, Interest Rate, Exchange Rate, Stock Return.

\section{PENDAHULUAN}

Pasar modal merupakan indikator kemajuan perekonomian suatu negara serta menunjang ekonomi negara yang bersangkutan. Pasar modal memiliki peran penting dalam membangun perekonomian suatu negara dengan menjalankan dua fungsi yakni sebagai sarana bagi emiten dalam memperoleh dana dari investor untuk pengembangan usaha dan sebagai sarana bagi masyarakat yang memiliki kelebihan dana untuk berinvestasi pada instrumen keuangan.

Salah satu instrumen keuangan yang paling banyak diminati oleh investor adalah saham, reksa danadan obligasi, karena memberikan keuntungan yang menarik. Pada saat krisis ekonomi menghantam Indonesia pada pertengahan 1997, kinerja pasar modal sempat mengalami penurunan tajam bahkan diantaranya mengalami kerugian. Kondisi ini akan mempengaruhi investor untuk melakukan investasi di pasar modal khususnya saham dan akan berdampak terhadap harga pasar saham di bursa.Selain itu krisis ekonomi juga dapat menyebabkan variabel-variabel ekonomi makroseperti inflasi, nilai tukar dan tingkat suku bunga mengalami perubahan yang cukup tajam.

Pasar modal dapat dijadikan sebagai alternatif investasi bagi investor yang ingin menginvestasikan kelebihan dana yang dimiliki pada beberapa perusahaan melalui pembelian efek yang transaksinya diperantarai oleh para anggota bursa. Pasar modal berperan penting dalam kegiatan perekonomian karena merupakan sumber dana alternatif bagi perusahaan-perusahaan. Pasar modal memiliki beberapa instrumen yang salah satunya adalah saham.Tujuan utama dalam berinvestasi saham adalah untuk memperoleh return.Return yang diperoleh berupa realized return atau expected return. Realized return merupakan return yang telah terjadi dan dihitung menggunakan data historis. Expected return merupakan return yang diharapkan akan diperoleh investor di masayang akan datang (Hartono, 2008: 195).

Return merupakan salah satu faktor yang memotivasi investor untuk berinvestasi dan juga merupakan imbalan atas keberanian investor menanggung risiko atas investasi yang 
dilakukannya (Tandelilin, 2010: 101). Investor dalam menanamkan modalnya berharap untuk memperoleh return sham yang sebesar-besarnya, oleh karena itu investor membutuhkan berbagai jenis informasi sehingga investor dapat menilai kinerja perusahaan yang diperlukan untuk pengambilan keputusan investasi.Secara garis besar informasi yang diperlukan investor terdiri dari informasi fundamental dan informasi teknikal.

Saham perusahaan yang go public atau telah terdaftar di bursa efek, merupakan investasi tergolong beresiko. Hal ini disebabkan sifatnya yang sangat dipengaruhi oleh perubahan-perubahan return saham, baik internal maupun eksternal perusahaan yang cenderung dapat dikontrol, sedangkan informasi fundamental adalah informasi kondisi makro ekonomi seperti tingkat pergerakan suku bunga, nilai tukar mata uang, inflasi. Informasi fundamental ini sering digunakan sebagai dasar analisis pasar modal.Dalam kondisi ekonomi makro dapat mempengaruhi operasi perusahaan sehari-hari.Hasil keputusan investor dengan menentukan investasi yang menguntungkan salah satunya dipengaruhi oleh kemampuan investor tersebut dalam memahami dan meramalkan kondisi ekonomi makro di masa datang.

Dalam ekonomi makro terdapat beberapa indikator yang harus dipertimbangkan investor dalam membuat keputusan investasinya. Menurut (Tandelilin, 2010: 341-343) bahwa variabel ekonomi makro yang perlu diperhatikan investor antara lain adalah tingkat inflasi, tingkat suku bunga SBI, nilai tukar rupiah, produk domestik bruto (PDB), anggaran defisit, investasi swasta, serta neraca perdagangan dan pembayaran. Kegiatan-kegiatan yang memperkuat perekonomian merupakan dorongan pertumbuhan laba dan pendapatan perusahaan sehingga mendorong peningkatan harga saham. Umumnya perekonomian yang stabil dan berkembang dengan pesat akan menghasilkan bull market di pasar modal karena pendapatan sektor bisnis juga mengalami peningkatan. Sebaliknya perekonomian yang tidak bertumbuh dan tidak stabil akan menghasilkan bear market.

Dalam peneliti ini penulis mengembangkan 3 variabel ekonomi makro yaitu inflasi, suku bunga dan nilai tukar.Menurut Putong (2008:133) inflasi adalah proses kenaikan hargaharga umum secara terus menerus. Kenaikan harga dari satu barang saja tidak disebut inflasi, kecuali bila kenaikan tersebut meluas kepada (mengakibatkan kenaikan) sebagian besar dari harga barang-barang lain. Dalam selưuruh kasus inflasi besar atau terus-menerus, pelakunya adalah pertumbuhan jumlah uang. Ketika pemerintah menciptakan uang dengan jumlah besar, maka nilai uang akan jatuh.inflasi yang tinggi akan menjatuhkan harga saham di pasar, sementara inflasi yang sangat rendah akan berakibat pada pertumbuhan ekonomi akan menjadi sangat lamban, dan pada akhirnya harga saham juga bergerak dengan lamban. Alasan memilih inflasi sebagai variabel daripada struktur modal adalah karena variabel ini menggambarkan salah satu fenomena ekonomi yang sangat menarik untuk dibahas terutama yang berkaitan dengan dampaknya yang luas terhadap agregat makro ekonomi karena semakin meningkat inflasi akan mengurangi pendapatan perusahaan.

Ada pun perkembangan return saham pada Perusahaan Manufaktur mengalami fluktuasi dari tahun 2013 ke tahun 2016 yaknipada tahun 2013 return saham mengalami kenaikandengan rata-rata sebesar 11,14 persen, sedangkan tahun 2014 return saham juga meningkat dengan rata-rata-11,30 persen, tetapi pada tahun2015 return saham mengalami penurunan dengan rata-rata $-3,18$ persen dan pada tahun 2016 return saham juga mengalami penurunan dengan rata-rata sebesar $-2,61$ persen. Berfluktuasi Return saham diatas disebabkan oleh banyak faktor diantaranya oleh faktor fundamental perusahaan dan faktor Makro ekonomi.Faktor makro ekonomi yang mempengaruhi return saham ini seperti inflasi, tingkat suku bunga, dan nilai tukar/kurs.

Objek pembahasan dalam penelitian ini adalah perusahaan manufaktur. Perusahaan manufaktur adalah perusahaan industri pengolahan bahan baku menjadi barang setengah jadi atau barang jadi. Perusahaan manufaktur identik dengan pabrik yang mengaplikasikan mesin-mesin peralatan, teknik rekayasa dan tenaga kerja.Istilah ini bisa digunakan untuk 
aktivitas manusia dari kerajinan tangan sampai ke produksi dengan teknologi tinggi. Namun demikian, istilah ini lebih sering digunakan untuk dunia industri, dimana bahan baku diubah menjadi barang jadi dalam skala besar. Perusahaan manufaktur dinilai mempunyai prospek cerah seiring dengan perkembangan ekonomi. Perusahaan ini dapat bertahan di tengah kondisi perekonomian indonesia karena pendiriannya yang semakin banyak diharapkan dapat memberikan prospek yang menguntungkan untuk memenuhi kebutuhan masyarakat. Dengan pertimbangan bahwa perusahaan manufaktur adalah salah satu sumber investasi di pasar uang dan mengalami dampak langsung dari perubahan variabel makro ekonomi, khususnya yang berhubungan dengan pilihan investor dalam berinvestasi.Sehingga dapat diketahui peneliti menggunakan Perusahaaan Manufaktur yang terdaftar di Bursa Efek Indonesia.

\section{TINJAUAN PUSTAKA}

\section{A. Investasi}

Menurut Sunariyah (2003:4) investasi adalah penanaman modal untuk satu atau lebih aktiva yang dimiliki dan biasanya berjangka waktu lama dengan harapan mendapatkan keuntungan di masa-masa yang akan datang.Sedangkan tujuan investasi mendapatkan sejumlah pendapatan atau keuntungan. Dalam konteks perekonomian, menurut Tandelilin (2001) ada beberapa motif mengapa seseorang melakukan investasi antara lain adalah:

1. Untuk mendapatkan kehidupan yang lebih layak merupakan keinginan setiap manusia, sehingga upaya upaya untuk mencapai hal tersebut dimasa depan selalu akan di lakukan.

2. Mengurangi tekanan inflasi. Faktor inflasi tidak pernah dapat dihindarkan dalam kehidupan ekonomi, yang dapat dilakukan adalah meminimalkan resiko akibat adanya inflasi, hal demikian karena variabel inflasi dapat menkoreksi seluruh pendapatan yang ada. Investasi dalam sebuah bisnis tentu dapat dikategorikan sebagai langkah mitigasi yang efektif.

3. Sebagai usaha untuk menghemat pajak.

Setiap keputusan investasi selalu menyangkut dua hal, yaitu risiko dan return. Risiko mempunyai hubungan positif dan linier dengan return yang diharapkan dari suatu investasi, sehingga semakin besar return yang diharapkan maka semakin besar pula risiko yang harus ditanggung oleh seorang investor. Dalam melakukan keputusan investasi, khususnya pada sekuritas saham, return yang diperoleh berasal dari dari dua sumber, yaitu dividen dan capital gain, sedangkan resiko investasi saham tercermin pada variabelitas pendapatan (return saham) yang di peroleh.

\section{B. Pasar modal}

Pasar modal adalah tempat atau sarana bertemunya antara permintaan dan penawaran atas instrumen keuangan jangka panjang, umumnya lebih dari satu tahun. Sedangkan menurut Sunariyah (2003: 2) pasar modal adalah suatu pasar (tempat) yang disiap gunakan dalam perdagangkan saham, obligasidan jenis surat berharga lainnya dengan memakai jasa para perantara pedagang efek.Maka dapat di simpulkan bahwa pasar modal merupakan sarana atau tempat bertemunya pihak yang memiliki kelebihan dana dan pihak yang kekurangan dana. Tujuan dan manfaat pasar modal dapat di lihat dari 3 sudut pandang, yaitu: (a) sudut pandang Negara, (b) sudut pandang emiten, dan (c) Sudut pandang masyarakat

Menurut Samsul (2006:43) instrumen yang ada pasar modal adalah sebagai berikut:

a. Saham. Saham adalah tanda bukti memiliki perusahaan dimana pemiliknya disebut juga sebagai pemegang saham (shareholder atau stockhoder). Bukti bahwa seseorang dapat dianggap sebagai pemegang saham adalah apabila mereka sudah tercatat sebagai pemegang saham dalam buku yang disebut Daftar Pemegang Saham (DPS). Hak kumulatif adalah hak untuk mendapatkan laba yang tidak dibagikan pada suatu tahun 
yang mengalami kerugian, sehingga saham preferenakan menerima laba dua kali. Saham biasa adalah jenis saham yang akan menerima laba setelah laba bagian saham preferen dibayarkan.

b. Obligasi (bond). Obligasi adalah tanda bukti perusahaan memiliki utang jangka panjang kepada masyarakat yaitu di atas 3 tahun. Pihak yang membeli obligasi disebut pemegang obligasi (bondholder) dan pemegang obligasi akan menerima kupon sebagai pendapatan dari obligasi yang dibayarkan setiap 3 bulan atau 6 bulan sekali. Pada saat pelunasan obligasi oleh perusahaan, pemegang obligasi akan menerima kupon dan pokok obligasi.

c. Bukti right. Bukti right adalah hak untuk membeli saham pada harga tertentu dalam jangka waktu tertentu. Hak pembelian itu dimiliki pemegang saham lama.Harga tertentu disini berarti harganya sudah ditetapkan di muka dan biasa disebut harga pelaksanaan atau harga tembusan (strike price atau exercise price).

\section{Return saham}

Menurut Menurut Hanafi dan Halim (1996 : 300), Return Saham disebut juga sebagai pendapatan saham dan merupakan perubahan nilai harga saham periode $t$ dengan $t-i$. Dan berarti bahwa semakin tinggi perubahan harga saham maka semakin tinggi return saham yang dihasilkan. Sedangkan Menurut Abdul Halim (2003:30) "Return adalah imbalan yang diperoleh dari investasi" Ada beberapa faktor yang dapat mempengaruhi Return Saham itu sendiri, beberapa faktor yang mempengaruhi harga atau ReturnSaham baik yang bersifat makro maupun mikro. Faktor Makro yaitu faktor-faktor yang berada di luar perusahaan, antara lain: Inflasi (2) Suku Bunga (3) Kurs Valuta Asing. Beberapa faktor yang mempengaruhi ReturnSaham menurut Resmi (2002) dalam Bramantyo (2006:2) menyatakan terdapat 2 (dua) macam analisis untuk menentukan ReturnSaham secara garis besar, yaitu informasi fundamental dan informasi teknikal. Informasi fundamental diperoleh dari intern perusahaan meliputi deviden dan tingkat pertumbuhan penjualan perusahaan, karakteristik keuangan, ukuran perusahaan sedangkan informasi teknikal diperoleh di luar perusahaan seperti ekonomi, politik dan finansial.

Return realisasi (actual return) Return realisasi merupakan return yang telah terjadi. Actual return digunakan dalam menganalisis data adalah hasil yang diperoleh dari investasi dengan cara menghitung selisih harga saham individual periode berjalan dengan periode sebelumnya dengan mengabaikan deviden, dapat ditulis dengan rumus

$$
\begin{array}{ll}
\mathrm{Ri}, \mathrm{t}=\frac{\mathrm{Pi}, \mathrm{t}-\mathrm{Pi}, \mathrm{t}-1}{\mathrm{Pi}, \mathrm{t}-1} & \\
\text { Keterangan: } & \\
\mathrm{Ri}, \mathrm{t} \quad=\text { ReturnSaham } \mathrm{i} \text { pada waktu } \mathrm{t} \\
\mathrm{Pi} \mathrm{t} \quad=\text { Harga Saham i pada periode } \mathrm{t} \\
\text { Pit-1 } \quad=\text { Harga Saham pada i periode } \mathrm{t}-1
\end{array}
$$

\section{Inflasi}

Inflasi adalah kenaikan harga dari satu atau dua barang dalam waktu yang singkat. Secara umum dan sederhana inflasi dapat disebabkan oleh dua hal yaitu inflasi yang timbul karena adanya permintaan masyarakat yang berlebih dan inflasi yang terjadi karena adanya kenaikan biaya produksi (Boediono, 1992 : 162). Menurut Putong (2008:133) inflasi adalah proses kenaikan harga-harga umum secara terus menerus. Kenaikan harga dari satu barang saja tidak disebut inflasi, kecuali bila kenaikan tersebut meluas kepada (mengakibatkan kenaikan) sebagian besar dari harga barang-barang lainnya. Inflasi merupakan suatu variabel ekonomi makro yang dapat sekaligus menguntungkan dan merugikan suatu perusahaan. Pada dasarnya inflasi yang tinggi tidak disukai oleh para pelaku pasar modal karena akan meningkatkan biaya produksi.Tingkat inflasi dapat berpengaruh positif maupun negatif tergantung pada derajat inflasi itu sendiri. Inflasi yang berlebihan dapat merugikan 
perekonomian secara keseluruhan, yaitu dapat membuat banyak perusahaan mengalami kebangkrutan. Jadi dapat di simpulkan bahwa inflasi yang tinggi akan menjatuhkan harga saham di pasar, sementara inflasi yang sangat rendah akan berakibat pada pertumbuhan ekonomi akan menjadi sangat lamban, dan pada akhirnya harga saham juga bergerak dengan lamban. Pekerjaan yang sulit adalah menciptakan tingkat inflai yang dapat menggerakkan dunia usaha menjadi semarak, pertumbuhan ekonomi akan dapat menutupi pengangguran, perusahan memperoleh keuntungan yang memadai, dan harga saham di pasar bergerak normal.

\section{E. Suku Bunga}

Menurut Mankiw (2003:86) bahwa tingkat bunga adalah harga yang menghubungkan masa kini dan masa depan. Sedangkan menurut Samuelson dan Nordhaus (2001), suku bunga adalah jumlah bunga yang di bayarkan per unit waktu yang disebut sebagai persentase dari jumlah yang dipinjamkan.Suku bunga dinyatakan sebagai persentase uang pokok per unit waktu.Bunga merupakan suatu ukuran harga sumber daya yang digunakan oleh debitur yang harus dibayarkan kepada kreditur.Tingkat bunga ditentukan oleh permintaan dan penawaran akan uang (ditentukan dalam pasar uang). Perubahan tingkat suku bunga selanjutnya akan mempengaruhi keinginan untuk mengadakan investasi, misalnya pada surat berharga, dimana harga dapat naik atau turun tergantung pada tingkat bunga (bila tingkat bunga naik maka surat berharga turun dan sebaliknya), sehingga ada kemungkinan pemegang surat berharga akan menderita capital loss atau capital gain. Suku bunga dibedakan menjadi dua, yaitu:

a. Suku bunga nominal adalah suku bunga dalam nilai uang. Suku bunga ini merupakan nilai yang dapat dibaca secara umum. Suku bunga ini menunjukkan sejumlah rupiah untuk setiap satu rupiah yang di investasikan.

b. Suku bunga riil adalah suku bunga yang telah mengalami koreksi akibat inflasi dan didefinisikan sebagai suku bunga nominal dikurangi laju inflasi.

Penentuan tingkat bunga haruslah memperhatikan tingkat inflasi yang terjadi. Hal ini diungkapkan Mankiw (2003:86) bahwa tingkat bunga nominal akan berubah karena dua alasan yaitu karena tingkat bunga rill berubah atau karena tingkat inflasi berubah jadi tingkat bunga nominal besarnya adalah penjumlahan dari tingkat bunga rill ditambah tingkat inflasi.

Mishkin (2008:4) mengemuakan suku bunga adalah biaya pinjaman atau harga yang dibayarkan untuk dana pinjaman tersebut. Oleh karena itu, bunga juga dapat diartikan sebagai uang yang diperoleh atas pinjaman yang diberikan.Suku bunga pada dasarnya mempunyai dua pengertian sesuai dengan peninjauannya yaitu bagi bank dan bagi pengusaha. Bagi bank, bunga adalah suatu pendapatan atau suatu keuntungan atas peminjaman uang oleh pengusaha atau nasabah. Dan bagi pengusaha bunga dianggap sebagai ongkos produksi ataupun biaya modal. Sedangkan Menurut Kewal (2012), Tingkat bunga yang terlalu tinggi akan mempengaruhi nilai sekarang (present value) aliran kas perusahaan, sehingga kesempatan-kesempatan investasi yang ada tidak akan menarik lagi. Tingkat bunga yang tinggi juga akan meningkatkan biaya modal yang akan ditanggung perusahaan dan juga akan menyebabkan return yang diisyaratkan investor dari suatu investasi akan meningkat.

Menurut Kewal (2012), Suku bunga dapat mempengaruhi harga saham dengan tiga cara yaitu:

1. Perubahan suku bunga dapat mempengaruhi kondisi perusahaan, kondisi bisnis secara umum dan tingkat profitabilitas perusahaan yang tentunya akan mempengaruhi harga saham di pasar modal.

2. Perubahan suku bunga juga akan mempengaruhi hubungan perolehan dari obligasi dan perolehan dividen saham, oleh karena itu daya tarik yang relatif kuat antara saham dan obligasi. 
3. Perubahan suku bunga juga akan mempengaruhi psikologis para investor sehubungan dengan investasi kekayaan, sehingga mempengaruhi harga saham.

Menurut (Weston dan Brigham, 1990:84) bahwa Suku Bunga mempengaruhi laba perusahaan dalam dua cara : (1) karena bunga merupakan biaya, maka makin tinggi tingkat Suku Bunga maka makin rendah laba perusahaan apabila hal-hal lain dianggap konstan; dan (2) Suku Bunga mempengaruhi tingkat aktivitas ekonomi, karena itu mempengaruhi laba perusahaan. Suku Bunga tidak diragukan lagi mempengaruhi investasi portofolio karena pengaruhnya terhadap laba, tetapi yang terpenting adalah Suku Bunga berpengaruh karena adanya persaingan di pasar modal antara saham dan obligasi. Suku Bunga yang tinggi di satu sisi akan meningkatkan hasrat masyarakat untuk menabung sehingga jumlah dana perbankan akan meningkat. Sementara itu, di sisi lain Suku Bunga yang tinggi akan meningkatkan biaya yang dikeluarkan oleh dunia usaha sehingga mengakibatkan penurunan kegiatan produksi di dalam negeri. Menurunnya produksi pada gilirannya akan menurunkan pula kebutuhan dana oleh dunia usaha. Hal ini berakibat permintaan terhadap kredit perbankan juga menurun sehingga dalam kondisi Suku Bunga yang tinggi, yang menjadi persoalan adalah ke mana dana itu akan disalurkan.

\section{F. Nilai Tukar/ kurs}

Nilai tukar merupakan perbandingan nilai atau harga antara dua mata uang yang berbeda. Diciptakannya sistem nilai tukar ini dimaksudkan untuk mempermudah transaksi barang dan jasa internasional (Nopirin, 2000: 163). Nilai tukar atau kurs adalah perbandingan nilai tukar mata uang suatu negara dengan mata uang negara asing atau perbandingan nilai tukar valuta asing antar negara (Sukirno, 2004). Kurs adalah tingkat harga yang disepakati penduduk kedua negara untuk saling melakukan perdagangan (Mankiw, 2006: 128). Hanafi (2003) menjelaskan yang dimaksud dengan apresiasi berarti meningkatnya nilai mata uang suatu negara relatif terhadap mata uang lainnya. Sedangkan depresiasi berarti sebaliknya, yaitu menurunnya nilai mata uang suatu negara terhadap mata uang lainnya. Kurs Bank Indonesia adalah kurs yang ditetapkan Bank Indonesia pada bursa valas di Jakarta. Sedangkan kurs jual adalah perbandingan nilai tukar matauang suatu negara dengan mata uang negara asing jika bank yang menjualnya atau masyarakat yang akan membelinya.Kurs beli adalah perbandingan nilai tukar mata uang asing jika bank yang akan membelinya atau masyarakat yang akan menjualnya.

Ada beberapa faktor utama yang mempengaruhi tinggi rendahnya nilai tukar mata uang dalam negeri terhadap mata uang asing. Faktor-faktor tersebut adalah :

a. Laju inflasi relatif. Dalam pasar valuta asing, perdagangan internasional baik dalam bentuk barang atau jasa menjadi dasar yang utama dalam pasar valuta asing, sehingga perubahan harga dalam negeri yang relatif terhadap harga luar negeri dipandang sebagai faktor yang mempengaruhi pergerakan kurs valuta asing.

b. Tingkat pendapatan relatif. Faktor lain yang mempengaruhi permintaan dan penawaran dalam pasar mata uang asing adalah laju pertumbuhan riil terhadap harga-harga luar negeri. Laju pertumbuhan riil dalam negeri diperkirakan akan melemahkan kurs mata uang asing. Sedangkan pendapatan riil dalam negeri akan meningkatkan permintaan valuta asing relatif di bandingkan dengan supply yang tersedia.

c. Suku bunga relatif. Kenaikan suku bunga mengakibatkan aktifitas dalam negeri menjadi lebih menarik bagi para penanam modal dalam negeri maupun luar negeri. Terjadinya penanaman modal cenderung mengakibatkan naiknya nilai 23 mata uang yang semuanya tergantung pada besarnya perbedaan tingkat suku bunga di dalam dan di luar negeri, maka perlu dilihat mana yang lebih murah, di dalam atau di luar negeri. Dengan demikian sumber dari perbedaan itu akan menyebabkan terjadinya kenaikan kurs mata uang asing terhadap mata uang dalam negeri. 
d. Ekspektasi. Faktor berikutnya yang mempengaruhi nilai tukar valuta asing adalah ekspektasi atau nilai tukar di masa depan. Sama seperti pasar keuangan yang lain, pasar valas bereaksi cepat terhadap setiap berita yang memiliki dampak ke depan.

e. Jumlah Uang Beredar (M2). Uang beredar adalah keseluruhan jumlah uang yang dikeluarkan secara resmi baik oleh bank sentral berupa uang kartal, maupun uang giral dan uang kuasi (tabungan, valas, deposito). Kemudian menurut Madura (2003:111-123), untuk menentukan perubahan nilai tukar antar mata uang suatu negara dipengaruhi oleh beberapa faktor yang terjadi di negara yang bersangkutan yaitu selisih tingkat inflasi, selisih tingkat suku bunga, selisih tingkat pertumbuhan GDP, intervensi pemerintah di pasar valuta asing dan expectations (perkiraan pasar atas nilai mata uang yang akan datang).

f. Neraca Pembayaran. Neraca pembayaran adalah catatan dari semua transaksi ekonomi internasional yang meliputiperdagangan, keuangan dan moneter antara penduduk dalam negeri dengan penduduk luar negeri selama periode waktu tertentu, biasanya satu tahun atau dikatakan sebagai laporan arus pembayaran (keluar dan masuk) untuk suatu negara. Neraca pembayaran secara esensial merupakan sistem akuntansi yang mengukur kinerja suatu negara. Pencatatan transaksi dilakukan dengan pembukuan berpasangan, yaitu; tiap transaksi dicatat satu sebagai kredit dan satu lagi sebagai debit.

\section{G. Pengaruh Inflasi terhadap Return Saham}

Inflasi merupakan kecenderungan kenaikan harga barang-barang secara umum yang terjadi terus menerus. Hal ini tentu saja akan mempengaruhi kenaikan biaya produksi pada suatu perusahaan. Sirait dan Siagian (2002), mengemukakan bahwa kenaikan inflasi dapat menurunkan capital gain yang menyebabkan berkurangnya keuntungan yang diperoleh investor.

Disisi perusahaan, terjadinya peningkata inflasi, dimana peningkatannya tidak dapat dibebankan kepada konsumen, dapat menurunkan tingkat pendapatan perusahaan.Biaya produksi yang tinggi tentu saja akan membuat harga jual barang naik, sehingga akan menurunkan jumlah penjualan yang akan berdampak buruk terhadap kinerja perusahaan yang tercermin dengan turunya Return Saham perusahaan tersebut. Kenaikan laju inflasi yang tidak diantisipasi tersebut akan meningkatkan harga barang dan jasa, sehingga konsumsi akan menurun. Selain itu kenaikan harga faktor produksi juga akan meningkatkan biaya modal perusahaan. Sehingga pengaruh dari kenaikan laju inflasi yang tidak diantisipasi tersebut akan menurunkan harga saham. Dari penjelasan ini dapat disimpulkan bahwa terdapat pengaruh positif dari perubahan tingkat inflasi yang tidak diantisipasi sebelumnya terhadap return saham.Sirait dan Siagian (2002), mengemukakan bahwa kenaikan inflasi dapat menurunkan capital gain yang menyebabkan berkurangnya keuntungan yang diperoleh investor. Disisi perusahaan, terjadinya peningkatan inflasi, dimana peningkatannya tidak dapat dibebankan kepada konsumen, dapat menurunkan tingkat pendapatan perusahaan. Inflasi akan meningkatkan pendapatan dan biaya perusahaan. Jika peningkatan biaya produksi lebih tinggi dari peningkatan harga yang dapat dinikmati oleh perusahaan, maka profitabilitas perusahaan akan turun. Jika profit yang diperoleh perusahaan kecil, maka akan menyebabkan investor enggan menanamkan modalnya di perusahaan tersebut, sehingga harga saham turun yang pada akhirnya juga berpengaruh terhadap return saham yang diperoleh investor

\section{H. Pengaruh Suku Bunga terhadap Return Saham.}

Menurut Cahyono (2000:117) terdapat 2 penjelasan mengapa kenaikan Suku Bunga dapat mendorong ReturnSaham turun. Pertama, kenaikan Suku Bunga mengubah peta hasil investasi. Kedua, kenaikan Suku Bunga akan memotong laba perusahaan. Hal ini terjadi dengan dua cara, Kenaikan Suku Bunga akan meningkatkan beban bunga emiten, sehingga 
labanya bisa terpangkas. Selain itu, ketika Suku Bunga tinggi, biaya produksi akan meningkat dan harga produk akan lebih mahal sehingga konsumen mungkin akan menunda pernbeliannya dan menyimpan dananya di bank. Akibatnya penjualan perusahaan menurun. Penurunan penjualan perusahaan dan laba akan menekan ReturnSaham.

Dalam literatur Financial Economicbanyak dibahas mengenai pengaruh perubahan pada tingkat diskonto (biaya modal) pada ReturnSaham. Salah satu penyebab perubahan tingkat diskonto (biaya modal) adalah perubahan tingkat suku bunga. Perubahan kebijakan moneter akan mempengaruhi pasar modal melalui perubahan yang terjadi pada pengeluaran konsumsi dan investasi. Penurunan pada tingkat bunga akan mendorong pengeluaran konsumsi dan investasi yang selanjutnya akan meningkatkan harga saham. Berdasarkan penjelasan tersebut dapat disimpulkan bahwa Suku Bunga berpengaruh negatif terhadap ReturnSaham. Adapun menurut Jogiyanto (2010) bahwa tingginya tingkat suku bunga deposito berakibat negatif terhadap pasar modal. Investor tidak lagi tertarik untuk menanamkan dananya di pasar modal, karena total return yang diterima lebih kecil dibandingkan dengan pendapatan dari bunga deposito. Akibat lebih lanjut, harga harga saham di pasar modal mengalami penurunan yang drastis. Sedangkan tandelilin (2001), tingkat bunga terlalu tinggi akan mempengaruhi nilai sekarang (presentvalue) aliran kas perusahaan, sehingga kesempatan kesempatan investasi yang ada tidak akan menarik lagi. Tingkat bunga yang tinggi juga akan meningkatkan biaya modal yang harus di tanggung perusahaan. Disamping itu tingkat bunga yang tinggi juga akan menyebabkan return yang disyaratkan investor dari suatu investasi akan meningkat.

\section{Pengaruh Nilai Tukar Rupiah terhadap Return Saham.}

Kurs valuta asing adalah salah satu alat pengukur lain yang digunakan dalam menilai kekuatan suatu perekonomian. Kurs menunjukkan banyaknya uang dalam negeri yang diperlukan untuk membeli satu unit valuta asing tertentu. Kurs valuta asing dapat dipandang sebagai harga dari suatu mata uang asing. Salah satu faktor penting yang mempengaruhi kurs valuta asing adalah neraca perdagangan nasional. Neraca perdagangan nasional yang mengalami defisit cenderung untuk menaikkan nilai valuta asing. Dan sebaliknya, apabila neraca pembayaran kuat (surplus dalam neraca keseluruhan) dan cadangan valuta asing yang dimiliki negara terus menerus bertambah jumlahnya, nilai valuta asing akan bertambah murah. Maka perubahan-perubahan kurs valuta asing dapat dipergunakan sebagai salah satu ukuran untuk menilai kestabilan dan perkembangan suatu perekonomian. Sehingga dapat dijelaskan bahwa apresiasi mata uang domestik akan meningkatkan volume ekspor. Bila permintaan pasar internasional cukup elastis, hal ini akan meningkatkan cash flow perusahaan domestik, kemudian meningkatkan harga saham. Meningkatnya harga saham ini berarti meningkatkan returnsaham. Sehingga dapat disimpulkan bahwa perubahan tingkat kurs mata uang domestik berpengaruh positif terhadap returnsaham. hal inidikarenakan peningkatan indeks nilai tukar (rupiah menguat), menyebabkan investorlebih memilih untuk berinvestasi dalam bentuk dollar (harga dollar semakin rendah).Permintaan terhadap saham menjadi turun, harga saham turun yang diikuti oleh penurunan return saham juga turun.

\section{J. Hipotesis Penelitian}

Berdasarkan teori yang dikemukakan sebelumnya maka dirumuskan hipotesis sebagai berikut: Inflasi, suku bunga dan nilai tukar secara parsial dan simultan berpengaruh signifikan terhadap ReturnSaham pada perusahaan manufaktur yang terdaftar di Bursa Efek Indonesia tahun 2013-2016.

\section{METODE PENELITIAN}

\section{A. Ruang Lingkup Penelitian}


Ruang lingkup penelitian adalah pengaruh inflasi, suku bunga dan nilai tukar/kurs terhadap return saham di Bursa Efek Indonesia periode 2013-2016. Data yang digunakan dalam penelitian ini adalah data sekunder dengan teknik dokumentasi.

\section{B. Populasi dan Sampel Penelitan}

Dalam penelitian ini populasi sebanyak 149 perusahaan manufaktur yang terdaftar di Bursa Efek Indonesia pada tahun 2013-2016.Metode pengambilan sampel yang digunakan adalah metode Slovin, maka Jumlah perusahaan yang dijadikan sampel dan memenuhi kriteria dalam pengambilan sampel di atas yaitu sebanyak 60 perusahaan manufaktur yang terdapat di Bursa Efek Indonesia,

\section{Variabel Dependent $(\mathrm{Y})$}

Variabel Dependent $(\mathrm{Y})$ dalam penelitian ini adalah return saham yang ada di Bursa Efek Indenesia selama periode Januari 2006 - Desember 2016. Return saham ini dinyatakan dalam persen pertahun dengan rumussebagai berikut:

$$
\begin{aligned}
\mathrm{Ri}, \mathrm{t}= & \frac{\mathrm{Pi}, \mathrm{t}-\mathrm{Pi}, \mathrm{t}-1}{\text { Pi,t-1 }} \\
\text { Keterangan: } & \\
\mathrm{Ri}, \mathrm{t} & =\text { Return Saham } \mathrm{i} \text { pada waktu } \mathrm{t} \\
\mathrm{Pi}, \mathrm{t} & =\text { Harga Saham } \mathrm{i} \text { pada periode } \mathrm{t} \\
\mathrm{Pit}-1 & =\text { Harga Saham pada i periode } \mathrm{t}-1
\end{aligned}
$$

\section{Variabel Independen $(X)$}

Dalam penelitian ini Variabel Independen/Variabel Bebas adalah

a. Inflasi (X1)

Inflasi merupakan suatu tingkat Inflasi yang terjadi pada pertriwulan.DataInflasi yang dipergunakan sebagai satuan persentase dalam penelitian ini adalah data pertahun pada Januari 2013-Desember 2016.

b. Suku Bunga (X2)

Tingkat Suku Bunga yang digunakan dalam penelitian ini merupakan tingkat Suku Bunga SBI.Pengukuran yang digunakan adalah satuan persentase dan data yang diambil adalah tingkat Suku Bunga SBI pertahunmulai tahun Januari 2013-Desember 2016.

c. Nilai Tukar Rupiah (X3)

Nilai tukar Rupiah/US\$ menunjukkan nilai dari mata uang Dolar AS yang ditranslasikan dengan mata uang Rupiah.Data yang diambil adalah nlai tukar Rupiah/US\$ pertahun mulai tahun Januari 2013 - Desember 2016.

\section{E. Teknik Pengumpulan Data}

Jenis data yang digunakan pada penelitian ini adalah data sekunder berupa laporan pertahun pada perusahaan manufaktur yang di publikasikan di Bursa Efek Indonesia selama periode 2013-2016.Sumber data yang digunakan untuk penelitian ini diperoleh dari situs resmi Bursa Efek Indonesia (BEI) yaitu www.idx.co.id, Biro Pusat Statistik (BPS) www.bps.go.id, Situs resmi Bank Indonesia yaitu www.bi.go.id, dan Pusat Referensi Pasar Modal (PRPM), dan Indonesian Capital Market Direktory (ICMD). Pengumpulan data yang digunakan dalam penelitian ini diperoleh melalui 2 cara yaitu: Studi Dokumentasi dan Penelitian Kepustakaan

\section{F. Teknik Analisis Data}

Teknik analisa data yang digunakan adalah linier regresi berganda dan diolah dengan program bantuan komputer yaitu SPSS 22.0 for Windows denganpersamaan:

$$
\mathrm{RS}=\alpha+\beta_{1} \mathrm{INF}+\beta_{2} \mathrm{SB}+\beta_{3} \mathrm{NT}+\mathrm{e}
$$


Volume 18 Nomor 2

Keterangan:
RS= Returnsaham Perusahaan
INF $=$ Inflasi
a $\quad=$ Konstanta
$\mathrm{SB}=$ Suku Bunga
$\beta_{1} \quad=$ Koefisien Regresi
NT $=$ Nilai Tukar

\section{G. Uji Asumsi Klasik}

Model regresi linier berganda harus memenuhi syarat asumsi klasik yang meliputi :uji Normalitas, uji Multikolinearitas, uji Autokorelasi, dan uji Heterokedastisitas. Adapun pengujian hipotesis dilakukan dengan uji tdan uji $\mathrm{F}$

\section{HASIL PENELITIAN DAN PEMBAHASAN}

\section{A. Hasil Penelitian}

Hasil analisis statistik deskriptif untuk variabel-variabel penelitian tersebut disajikan pada Tabel 1 berikut :

Tabel 1. Descriptive Statistics

\begin{tabular}{|l|c|r|r|r|r|}
\hline & N & Minimum & Maximum & \multicolumn{1}{c|}{ Mean } & Std. Deviation \\
\hline Return Saham & 240 & -98.21 & 87.62 & -7.0576 & 33.02060 \\
\hline Inflasi & 240 & 5.13 & 7.50 & 5.9575 & 1.47485 \\
\hline Suku Bunga & 240 & 5.96 & 7.54 & 7.1500 & .66539 \\
\hline Nilai Tukar & 240 & 10511.17 & 13456.36 & 12317.7000 & 1209.80898 \\
\hline Valid N(listwise) & 240 & & & & \\
\hline
\end{tabular}

Sumber : Hasil Pengolahan SPSS 22.00

Berdasarkan Tabel 1 di atas nampak bahwa tingkat inflasi selama periode pengamatan Januari 2013 - Desember 2016 memiliki nilai minimum sebesar 5,13 dan nilai maksimum sebesar 7.50. Nilai rata-rata sebesar 5,9575dengan simpangan baku sebesar 1,47485. Tingkat Suku Bunga selama periode pengamatan Januari 2013 - Desember 2016 memiliki nilai minimum sebesar 5.96 dan nilai maksimum sebesar 7,54. Nilai rata-rata sebesar 7,1500dengan simpangan baku sebesar 0,66539. Nilai Tukar/kurs selama periode pengamatan Januari 2013 Desember 2016 memiliki nilai minimum sebesar 10511,17 dan nilai maksimum sebesar 13456,36 dengan rata-rata sebesar 12317,7000 dengan simpangan baku sebesar 1209,80898.Nilai Return Saham selama periode pengamatan Januari 2013 - Desember 2016 memiliki nilai minimum sebesar -98,21 oleh INRU dan nilai maksimum sebesar87,62 oleh KAEF dengan rata-rata Return Saham Sebesar $-7,0576$ dengan standar deviasi sebesar 33,02060 .

\section{B. Hasil Uji Asumsi Klasik}

Berdasarkan uji asumsi klasik diperoleh bahwa nilai JB lebih kecil dari $\chi^{2}$ table, nilai VIF dibawah 10, tidak ada pola yang jelas serta titik-titik menyebar di atas dan dibawah angka nol pada sumbu $y$, dan nilai $d>d u$, makadengan demikian data telah memenuhi uji asumsi klasik yakni: data telah normalitas, dan terbebas dari Multikolonieritas, heteroskedastisitas dan Autokorelasi

\section{Pengujian hipotesis}

Adapun hasil pengujian pengaruh secara parsial antara inflasi, suku bunga dan nilai tukar/kurs terhadap Return Saham Perusahaan Manufaktur di Bursa Efek Indonesia dapat dilihat pada Tabel 2. berikut:

Tabel 2. Coefficientsa

\begin{tabular}{|l|c|c|c|c|c|}
\hline \multirow{2}{*}{ Model } & \multicolumn{2}{|c|}{$\begin{array}{c}\text { Unstandardized } \\
\text { Coefficients }\end{array}$} & $\begin{array}{c}\text { Standardized } \\
\text { Coefficients }\end{array}$ & \multirow{2}{*}{ Sig. } \\
\cline { 2 - 4 } & B & Std. Error & Beta & \multirow{t}{*}{ Sig. } \\
\hline
\end{tabular}




\begin{tabular}{|l|l|r|r|r|r|r|}
\hline 1 & (Constant) & -854.301 & 315.977 & & -2.704 & .007 \\
\cline { 2 - 7 } & Inflasi & 115.898 & 67.416 & 1.014 & 1.719 & .087 \\
\cline { 2 - 7 } & $\begin{array}{l}\text { Suku } \\
\text { Bunga }\end{array}$ & -295.730 & 171.716 & -.885 & -1.722 & .086 \\
\cline { 2 - 7 } & Nilai Tukar & 130.148 & 49.059 & .399 & 2.653 & .009 \\
\hline
\end{tabular}

a. Dependent Variable: Return Saham

Sumber: Hasil Pengolahan SPSS 22.00

Dari Tabel 2 di atas nampak bahwa secara parsial variabel Inflasi dan suku bunga mempunyai pengaruh positif dan tidak signifikan terhadap return saham pada alpa 5 persen, sedangkan variabel nilai tukar/kurs mempunyai pengaruh positif dan signifikan terhadap return saham pada alpa 5 persen. Adapun hasil pengujian secara simultan pengaruh Inflasi, suku bunga dan Nilai tukar/kurs terhadap Return Saham Perusahaan manufaktur yang terdaftar di Bursa Efek Indonesia periode Januari 2013 - Desember 2016 dapat dilihat pada Tabel 3. berikut.

Tabel 3. Anova

\begin{tabular}{|l|l|r|r|r|c|c|}
\hline \multicolumn{2}{|l|}{ Model } & Sum of Squares & \multicolumn{1}{c|}{ df } & Mean Square & F & Sig. \\
\hline \multirow{3}{*}{1} & Regression & 11483.850 & 3 & 3827.950 & 3.635 & $.014^{\mathrm{b}}$ \\
\cline { 2 - 7 } & Residual & 248512.783 & 236 & 1053.020 & & \\
\cline { 2 - 7 } & Total & 259996.633 & 239 & & & \\
\hline \multicolumn{7}{|l}{ a. Dependent Variable: Return Saham } \\
\hline
\end{tabular}

Sumber :data diolah, 2018

Berdasarkan tabel 3 di atas nampak bahwa variable inflasi, suku bunga, nilai tukar/kurs secara simultan mempunyai pengaruh yang signifikan terhadap return saham pada tingkat alpa 5 persen. Hasil koefisien determinasi $\left(R^{2}\right)$ diperoleh sebesar 0.044 . Hal ini berarti bahwa besarnya variasi Return Saham mampu dijelaskan oleh variabel makro ekonomi seperti Inflasi, suku bunga dan nilai tukar/kurs pada perusahaan manufaktur yang terdapat di Bursa Efek Indonesia periode Januari 2013 -Desember 2016 sebesar 4.4 persen. Sedangkan sisanya sebesar 95,6\% dijelaskan oleh variabel lainnya

\section{Pembahasan}

Inflasi adalah suatu proses meningkatnya harga-harga secara umum dan terus-menerus (kontinu) berkaitan dengan mekanisme pasar yang dapat disebabkan oleh berbagai faktor, antara lain, konsumsi masyarakat yang meningkat, berlebihnya likuiditas di pasar yang memicu konsumsi atau bahkan spekulasi, sampai termasuk juga akibat adanya ketidaklancaran distribusi barang. Berdasarkan hasil uji hipotesis pada tabel 2 di atas, variabel inflasi diperoleh koefisien regresi dengan arah positif sebesar 115,898 dan secara parsial variabel inflasi tidak berpengaruh signifikan terhadap return saham. Jadi jika inflasi naik Harga Saham turun maka return saham juga akan menurun karena investor takut melakukan investasi di pasar modal karena tidak mau menanggung resiko sehingga permintaan akan saham menurun yang mengakibatkan harga saham di pasar modal turun sehingga berdampak return saham.Dalam hal ini Hubungan antara inflasi dan return saham juga dikemukakan oleh Spyrou dalam Indrayadi, 2004), yang meneliti pada beberapa emerging stock markets, inflasi berkorelasi secara negatif dengan tingkat pengambilan investasi pada saham.Kenyataan tersebut mengindikasikan bahwa dengan tingkat inflasi yang tinggi dapat diharapkan dengan tingkat pengembalian investasi pada saham yang tinggi pula.

Tingkat suku bunga adalah salah satu dari variabel makro yang selalu menunjukkan perubahan dari waktu ke waktu atau tidak bersifat konstan. Berdasarkan uji hipotesis pada tabel 2 menunjukkan bahwa variabel suku bunga diperoleh koefisien regresi dengan arah 
negati sebesar $-295,730$ dan secara parsial variabel Suku bunga mempunyai pengaruh negatif dan tidak signifikan terhadap return saham pada alpa 5 persen. Sesuai dengan yang di ungkapkan oleh Mankiw (2003:86) bahwa tingkat bunga nominal akan berubah karena dua alasan yaitu karena tingkat bunga rill berubah atau karena tingkat inflasi berubah jadi tingkat bunga nominal besarnya adalah penjumlahan dari tingkat bunga rill ditambah tingkat inflasi. Jadi dapat di simpulkan bahwa suku bunga berpengaruh negatif dan tidak berpengaruh signifikan terhadap return saham. Jika tingkat suku bunga meningkat maka harga sham akan menurun sehingga return saham akan turun, hal ini disebabkan tingginya suku bunga menyebabkan investor akan menarik investasinya pada saham dan memindahkan investasinya pada tabungan atau deposito.

Besarnya nilai tukar mata uang suatu negara terhadap mata uang lainnya biasanya ditentukan oleh keadaan perekonomian suatu negara.Nilai tukar untuk ini lebih dikenal dengan Kurs. Puspopranoto (2004:212) mengemukakan bahwa Kurs merupakan harga dimana mata uang suatu negara dipertukarkan dengan mata uang negara lain disebut nilai tukar (kurs). Berdasarkan uji hipotesis menunjukkan bahwa nilai tukar/kurs berpengaruh positif dan signifikan terhadap return saham Perusahaan Manufaktur di Bursa Efek Indonesia periode Januari 2013 - Desember 2016 pada alpa 5 persen.Hasil penelitian ini sesuai dengan teori yang dijelaskan di atas yang menyatakan nilai tukar/kurs berpengaruh positif terhadap return saham. Hasil penelitian yang di lakukan penulis pada periode Januari 2013 - Desember 2016 bahwa nilai tukar/ kurs mengalami depresiasi (mata uang Rp melemah), jadi nilai tukar/kurs berpengaruh positif terhadap return pasar sehingga investor cenderung lebih memilih berinvestasi di dalam bentuk saham. Maka permintaan terhadap saham akan meningkat dan harga saham akan meningkat yang di ikuti dengan peningkatan return saham.

\section{KESIMPULAN}

Berdasarkan hasil penelitian dan pembahasan yang telah diuraikan pada bab terdahulu maka dapat ditarik kesimpulan sebagai berikut:Inflasi dan suku bungasecara parsial mempunyai pengaruh negatif dan tidak signifikan terhadap returnsaham, sedangkan nilai tukar secara parsial mempunyai pengaruh positif dan berpengaruh signifikan terhadap return saham pada Perusahaan Manufaktur di Bursa Efek Indonesia periode Januari 2013 Desember 2016. Secara simultan variabel Inflasi, suku bunga dan Nilai Tukar/Kurs berpengaruh positif dan signifikan terhadap Return Saham Perusahaan Manufaktur di Bursa Efek Indonesia periode Januari 2013 - Desember 2016.

\section{DAFTAR PUSTAKA}

Abdul Halim. (2005). Analisis Investasi. Edisi ke Dua. Jakarta : Salemba Empat.

Bramantyo. (2006). "Pengaruh Debt to Equity Ratio (DER), Price To Book Value (PBV), dan Devidend Payout Ratio (DPR) Terhadap Return Saham Pada Perusahaan Manufaktur".

Skripsi. Fakultas Ilmu Sosial: Universitas Negeri Semarang.

Bodiono.1998. “Ekonomi Makro". Edisi Empat.Yogyakarta: BPFE

Cahyono, J. E. (2000). Menjadi Manajer Investasi Bagi Diri Sendiri. Jakarta: Gramedia Pustaka Utama.

Hanafi, Mahmud dan Abdul Halim, 1996, Analisis Laporan Keuangan, Edisis Pertama, Yogyakarta: UPP AMP YKKPN.

Hantono dan Girsang.(2016). “Analisis Tingkat Bunga, Inflasi, Likuiditas, Nilai Tukar, Dan

Financial yang Mempengaruhi Terhadap Keuntungan Saham Dibursa Efek Indonesia".Jurnal. Fakultas Ekonomi, Universitas Prima Indonesia.

Jogyanto, H,(2013). “Teori Portofolio dan Analisis Investasi”. Edisi Ketiga. Cetakan Pertama. Yogyakarta: BPFE.

Mankiw. 2003. “Pengantar Ekonomi”. Edisi Kedua. Jakarta: Erlangga. 
. 2006. "Pengantar Ekonomi Makro". Edisi Ketiga. Jakarta: Salemba Empat.

Kewal.(2012). "Pengaruh Inflasi, Suku Bunga, Nilai Tukar Dan Pertumbuhan PDP Terhadap Indeks Harga Saham Gabungan". Fakultas Ekonomi: Sekolah Tinggi Ilmu Ekonomi Musi Palembang. Pelembang.

Mishkin, Frederich S. (2008). “Ekonomi Uang, Perbankan, dan Pasar Keuangan”. Edisi Delapan. Salemba Empat : Jakarta.

Putong, Iskandar. 2008. "Pengantar Ekonomi Mikro dan Makro". Jakarta: Ghalia Indonesia.

Samuelson,Paul A dan Nordhaus William D. 2001."Makro ekonomi”.Edisi Keempat belas.Jakarta.Erlangga.

Samsul.(2006). "Pasar Modal Dan Manajemen Portofolio". Penerbit Erlangga. Surabaya.

Sirait dan Siagian. 2002. Analisa Keterkaitan Sektor Riil, Sektor Moneter Dan Sektor Luar

Negeri dengan Pasar Modal. Jurnal Ekonomi Perusahaan .Vol no 2.

Sukirno.(2004). "Makro Ekonomi Suatu Pengantar", Edisi ketiga, cetakan keenambelas, Jakarta: PT Rajagrafindo Persada.

. 2006. "PengantarTeori Makro Ekonomi”. Jakarta: PT Raja Grafindo Persada.

Sunariyah. 2006. "Pengantar Pengetahuan Pasar Modal”. Yogyakarta: UUP AMP YKPN.

Suyati. (2015). "Pengaruh Tingkat Suku Bunga, Tingkat Inflasi, Nilai Kurs Rupiah/ US

Terhadap Return Saham Perusahaan Properti yang terdaftar Di Bursa Efek Indonesia

Terhadap Return Saham". Jurnal.Fakultas Ekonomi dan Bisnis.UNTAG. Semarang.

Tandelilin.(2001). "Analisis Investasi dan Manajemen Portofolio". Edisi Pertama. Yogyakarta.BPFE.

.(2010)."Portofolio dan Investasi Teori dan Aplikasi", Edisi Pertama, Kanisius IKAPI Yogyakarta.

Weston, J. Fred dan Brigham, Eugene F. (1990).“Dasar-Dasar Manajemen Keuangan”. Jilid I.

Edisi Kesembilan. Jakarta. Erlangga.

http://www.bi.go.id/id/moneter/inflasi/data/Default.aspx. Diakses pada tanggal 27 Februari 2017.

http://www.bi.go.id/id/moneter/bi-rate/data/Default.aspx. Diakses tanggal 2 Maret 2017.

http://www.idx.co.id.Diakses tanggal 1 Mei 2017. 